\title{
Pathological changes in placentas of pregnant females with Gestational hypertension
}

\author{
Dhakal Binod ${ }^{1}$,Singh $\mathrm{VK}^{2}$, Narasimhan Raghavan ${ }^{2}$, Talwar $\mathrm{OP}^{2}$
}

\section{Affiliations:}

${ }^{1}$ Department of Pathology

Kathmandu University School of Medical Sciences

Dhulikhel, Kavre, Nepal

${ }^{2}$ Department of Pathology

Manipal college of medical sciences

Phulbari, Pokhara

\section{Correspondence to:}

Dr. Binod Dhakal

Department of Pathology

Kathmandu University School of Medical Sciences

Dhulikhel, Kavre, Nepal

Email:dbinod@gmail.com

Received: 12 July, 2021 Accepted: 9 Nov, 2021

How to cite this Article:

Dhakal B, Singh VK, Narasimhan R, Talwar OP. Pathological changes in placentas of pregnant females with Gestational hypertension. Ann. Clin. Chem. Lab. Med. 2021:4(1);20-25

DOI: https://doi.org/10.3126/acclm.v4i1.42677

\section{(C) 2022 Nepalese Association for Clinical Chemistry}

\section{(D) (0)}

This work is licensed under a Creative Commons Attribution-Share Alike 4.0 International License.

\begin{abstract}
\section{BACKGROUND}

Hypertensive disorders complicating pregnancy are common and contribute greatly to maternal and fetal morbidity and mortality. The complications of hypertensive disorders in pregnancy have been attributed to abnormalities in the placenta. This study aims to observe the clinical, gross and microscopical (morphology) effects of pregnancy induced hypertension, preeclampsia and Eclampsia.
\end{abstract}

\section{METHODS}

It was a prospective study conducted in 30 placentas of hypertensive disorder of pregnancy and 20 placentas of normal pregnancy. The placentas with hypertensive disorders of pregnancy were compared with the placentas of normal pregnancy.

\section{RESULTS}

The mean age of mother at delivery was 28.1 years, 25.04 years and 25.04 years in pregnancy induced hypertension, preeclampsia and normal pregnancy respectively. The mean birth weight of new born babies, the mean placental weight and volume were found to be much lower than the control group. The risk for prematurity along with gross and histological abnormalities such as the presence of necrosis, villous hypermaturity, lymphohistiocytic villitis, avascular villi, perivillous fibrin deposits, hyalinization, stromal fibrosis, calcification and vessel wall thickening were observed significantly more often in the placentas of hypertensive mothers.

\section{CONCLUSION}

There is a significant Gross and microscopic changes observed in placentas of hypertensive mothers than the normal mothers. Similarly placental weight and volume were found to be much lower.

\section{KEY WORDS}

Eclampsia, Placental Changes, Pregnancy induced hypertension, preeclampsia. 


\section{INTRODUCTION}

Placenta is a unique organ that arise de novo, directly related to the growth and development of the fetus in the uterus. It is an organ of vital importance for the continuation of pregnancy and fetal nutrition. ${ }^{1}$ Since all anabolites needed for fetal metabolism come from the mother's blood and fetal catabolites are passed back into the mother's circulation through the placenta, the examination of placenta gives a clear idea of what had happened with it, when it was in the mother's womb and what is going to happen with the fetus in future. ${ }^{2}$

The term gestational hypertension is used to describe any form of new-onset pregnancyrelated hypertension. There are of five types: (1) Pregnancy induced hypertension (PIH) (2) Preeclampsia (PE) (3) Eclampsia (4) Preeclampsia superimposed on chronic hypertension and (5) Chronic hypertension. ${ }^{3}$ Hypertensive disorders complicating pregnancy are common and along with hemorrhage and infection contribute greatly to maternal and fetal morbidity and mortality. Many studies estimate that hypertension is responsible for $2.6 \%$ to $7.6 \%$ of maternal deaths. ${ }^{4}$ Pregnancies complicated with Preeclampsia have a high incidence of preterm delivery, fetal growth restriction, low birth weight, placental abruption, caesarian delivery, liver insufficiency, sub capsular liver hematoma, cerebral edema, renal failure, thrombocytopenia, and intravascular coagulation. ${ }^{5}$ The complications of hypertensive disorders in pregnancy have been attributed to abnormalities in the placenta. ${ }^{6,7,8}$ Therefore the placenta of the hypertensive woman has gained much interest.

Diagnosis of gestational hypertension is made in women whose blood pressure reaches 140/90 $\mathrm{mm} \mathrm{Hg}$ or greater for the first time during pregnancy but in whom proteinuria is not identified. Gestational hypertension is also called transient hypertension if preeclampsia does not develop and the blood pressure returns to normal by 12 weeks postpartum. Thus the gestational hypertension is a diagnosis of exclusion. ${ }^{4}$ Maternal and perinatal morbidity and mortality as a result of hemorrhage, infection and hypertensive pregnancy are major cause of maternal mortality rate in developing countries like Nepal. The main objective of the study was to observe and analyze the Clinical and Gross placental changes in PIH, PE and Eclampsia and compare them with placentas of normal pregnancy.

\section{METHODS}

It was a prospective study in which 30 cases of placentas with pregnancy induced hypertension and 20 with normal pregnancy (control group) were taken in a period of 2 years at department of Pathology. Mothers were examined clinically (for height, weight, blood pressure, pulse, pallor, anaemia, jaundice, cyanosis, edema etc.) along with recording of their medical history (history of past illness, surgical history, medical history, history of previous child birth etc). Blood pressure measurements and investigation of proteinuria were noted. Gestational age was assessed by the last menstrual period or by a first trimester ultrasound scan if there was a discrepancy of more than a week.

After collection of placenta along with the attached cord they were rinsed in water and left to drain of blood. After gross examination for umbilical vessels abnormality and calcification the placenta were weighed without umbilical cord. The samples were formalin fixed, sliced and kept in tissue processing and staining procedures. Placentas of uncomplicated pregnancy with adequate fetal growth were taken as control group. All the gross and microscopic findings were compared with placenta of normal pregnancy (the control group) and were accessed by SPSS software version 16 . Mean value, standard deviation, standard error, and 95\% confidence interval described the continuous variables. The ANOVA test was used to determine whether there was a statistical significance between control and hypertensive groups. A p-value $<0.05$ represents statistical significance in hypothesis testing and 95\% confidence intervals were used to describe the estimation of unknown parameters.

\section{RESULTS}

50 placentas were taken that included 20 $(40 \%)$ placentas with normal pregnancy (taken as control), 7 (14\%) placentas with PIH and 23 (46\%) placentas with PE. No eclampsia cases were available during the time of study. 
Table 1: Correlation of maternal and fetal data among Normal, PIH and PE.

\begin{tabular}{|c|c|c|c|c|}
\hline & $\begin{array}{l}\text { Normal } \\
\text { (mean } \pm \\
\text { SD) }\end{array}$ & $\begin{array}{l}\text { PIH } \\
\text { (mean } \pm \\
\text { SD) }\end{array}$ & $\begin{array}{l}\text { PE } \\
\text { (mean } \pm \\
\text { SD) }\end{array}$ & p value \\
\hline $\begin{array}{l}\text { Mean } \\
\text { age of } \\
\text { mother }\end{array}$ & $\begin{array}{l}25.65 \pm \\
4.39\end{array}$ & $\begin{array}{l}28.14 \pm \\
5.3\end{array}$ & $\begin{array}{l}25.04 \pm \\
5.7\end{array}$ & $\mathrm{p}=0.391$ \\
\hline $\begin{array}{l}\text { Gesta- } \\
\text { tional } \\
\text { age at } \\
\text { delivery } \\
\text { (WOG) }\end{array}$ & $\begin{array}{l}37.8 \pm \\
2.1\end{array}$ & $\begin{array}{l}34.57 \pm \\
2.9\end{array}$ & $\begin{array}{l}35.04 \pm \\
2.9\end{array}$ & $\mathrm{p}=0.002$ \\
\hline $\begin{array}{l}\text { Mean } \\
\text { Systolic } \\
\text { Blood } \\
\text { Pressure } \\
\text { (mm Hg) }\end{array}$ & $\begin{array}{l}112 \pm \\
11.8\end{array}$ & $\begin{array}{l}158.2 \pm \\
20.5\end{array}$ & $\begin{array}{l}157.3 \pm \\
20.0\end{array}$ & $\mathrm{p}<0.001$ \\
\hline $\begin{array}{l}\text { Mean } \\
\text { Diastolic } \\
\text { blood } \\
\text { pressure } \\
\text { (mm Hg) }\end{array}$ & $74 \pm 10.7$ & $98 \pm 3.2$ & $103 \pm 9.6$ & $\mathrm{p}<0.001$ \\
\hline
\end{tabular}

No differences existed between the groups regarding maternal age, whereas risk of PIH and PE were significantly increased in preterm $(<35$ WOG) deliveries than the control group (Table 1).

Table 2: Placental Morphometric study and its correlation among normal pregnancy, PIH and PE

\begin{tabular}{|c|c|c|c|c|}
\hline & $\begin{array}{l}\text { Normal } \\
\text { (mean } \pm \\
\text { SD) }\end{array}$ & $\begin{array}{l}\text { PIH } \\
\text { (mean } \pm \\
\text { SD) }\end{array}$ & $\begin{array}{l}\text { PE } \\
(\text { mean } \pm \\
\text { SD) }\end{array}$ & p value \\
\hline $\begin{array}{l}\text { Mean } \\
\text { Birth } \\
\text { weight of } \\
\text { babies in } \\
\text { kg }\end{array}$ & $2.7 \pm 0.3$ & $2.1 \pm 0.6$ & $\begin{array}{c}1.85 \pm \\
0.6\end{array}$ & $\mathrm{p}<0.001$ \\
\hline $\begin{array}{l}\text { Mean } \\
\text { placental } \\
\text { weight in } \\
\text { grams }\end{array}$ & $\begin{array}{l}526 \pm \\
103.6\end{array}$ & $\begin{array}{c}450.14 \pm \\
25.1\end{array}$ & $\begin{array}{c}413.4 \pm \\
116.5\end{array}$ & $\mathrm{p}=0.004$ \\
\hline $\begin{array}{c}\text { Mean } \\
\text { placental } \\
\text { volume in } \\
\text { cc }\end{array}$ & $\begin{array}{c}669.8 \pm \\
348.9\end{array}$ & $\begin{array}{l}352 \pm \\
213.5\end{array}$ & $\begin{array}{c}400.65 \pm \\
270.3\end{array}$ & $\mathrm{p}=0.008$ \\
\hline $\begin{array}{l}\text { Mean } \\
\text { feto pla- } \\
\text { cental } \\
\text { weight } \\
\text { ratio }\end{array}$ & $5.3 \pm 1.2$ & $4.8 \pm 0.9$ & $4.4 \pm 0.9$ & $\mathrm{p}=0.045$ \\
\hline
\end{tabular}

Placentas weighing less than 250 grams were found only in PE. As severity of hypertension increased, placental weight decreased. In nor- mal deliveries all were live born. Nineteen $(82 \%)$ of the PE babies were of low birth weight (weight $<2500 \mathrm{~g}$ ) and 2 were still born. Six (85.7) of the PIH babies were of low birth weight. There were no still born babies in PIH and control group.

Table 3: Gross morphology of placentas and its correlation among study groups.

\begin{tabular}{c|c|l|l|}
\cline { 2 - 4 } & Normal & PIH & PE \\
\hline $\begin{array}{c}\text { Marginal in- } \\
\text { sertion of um- } \\
\text { bilical cord }\end{array}$ & $3(15 \%)$ & $2(28.57 \%)$ & $\begin{array}{c}11(47.82 \\
\%)\end{array}$ \\
\hline $\begin{array}{c}\text { Infarction of } \\
\text { placenta in } \\
\text { number }\end{array}$ & - & $2(28.5 \%)$ & $9(39.1 \%)$ \\
\hline Calcification & $5(25 \%)$ & $2(28.57 \%)$ & $9(39.1 \%)$ \\
\hline
\end{tabular}

Table 4: Histopathological correlation of placentas among study groups.

\begin{tabular}{|c|c|c|c|}
\hline & Normal & PIH & PE \\
\hline $\begin{array}{l}\text { Villous hy- } \\
\text { permaturation }\end{array}$ & $10(50 \%)$ & $6(85.7 \%)$ & $23(100 \%)$ \\
\hline $\begin{array}{l}\text { Lymphohis- } \\
\text { tioytic villitis }\end{array}$ & $2(10 \%)$ & $5(71.3 \%)$ & $27(73.8 \%)$ \\
\hline Avascular villi & $2(10 \%)$ & $5(71.4 \%)$ & $19(82.6 \%)$ \\
\hline $\begin{array}{l}\text { Perivillous } \\
\text { fibrin deposits }\end{array}$ & $7(35 \%)$ & $6(85.7 \%)$ & $\begin{array}{c}20 \\
(86.95 \%)\end{array}$ \\
\hline $\begin{array}{l}\text { Stromal fibro- } \\
\text { sis }\end{array}$ & $11(55 \%)$ & $6(85.7 \%)$ & $20(86.9 \%)$ \\
\hline $\begin{array}{l}\text { Fibrinoid ne- } \\
\text { crosis }\end{array}$ & 0 & $1(14.3 \%)$ & $\begin{array}{c}16 \\
(69.56 \%)\end{array}$ \\
\hline $\begin{array}{l}\text { Vessel wall } \\
\text { thickening }\end{array}$ & $2(10 \%)$ & $3(42 \%)$ & $10(43 \%)$ \\
\hline Syncytial knot & $3(15 \%)$ & $5(71.3 \%)$ & $19(82 \%)$ \\
\hline Calcification & $10(50 \%)$ & $4(57 \%)$ & $20(86 \%)$ \\
\hline Hyalinization & $3(15 \%)$ & $3(42 \%)$ & $14(60 \%)$ \\
\hline $\begin{array}{l}\text { No of vessels } \\
\text { per field of } \\
\text { vision }\end{array}$ & $57.6 \pm 4.6$ & $48.4 \pm 6.9$ & $\begin{array}{c}38.26 \pm \\
11.09\end{array}$ \\
\hline
\end{tabular}




\section{DISCUSSION}

In the present study, the minimum age of the cases was 17 years and maximum age was 39 years. Maximum number of cases was recorded at the third decades of life. The commonest age range of the mothers in PIH and PE was 20 - 24 years. The age range of 25 - 29 years was the next common. Akhlaq $\mathrm{M}$ et al., also reports the commonest age range of the mothers in PE as 24-28 years and the age range of 18-23 years as the next common group. This is similar to this study. ${ }^{9}$

The mean age of the mother in this study was 25.6, 28.1 and 25.0 years in Normal, PIH and PE deliveries respectively. Obed SA et al, ${ }^{10}$ Hansen $\mathrm{JP}^{11}$ concluded that the risk of PIH increased with maternal age. However our study showed the discrepancy in findings regarding $\mathrm{PE}$ cases. The exact reason for the difference is not known but the discrepancy' may be due to the small amount of sample number taken in the study. There was also a trend towards higher rates of pre-term delivery ( $<37$ weeks), small for gestational age babies, stillbirth in $\mathrm{PIH}, \mathrm{PE}$ and Eclampsia as compared to the normal pregnancy group. Lydakis $\mathrm{C}$ et al. and Noor $\mathrm{S}$ et al. stated that there is a higher rate of preterm deliveries among PIH. ${ }^{12,13}$ The reason may be related to aging of the uterine blood vessels.

This study showed the mean gestational age of deliveries of PIH and PE was significantly less than normal deliveries. There were $2(8.6 \%)$ cases with prenatal mortality in case of $\mathrm{PE}$ which is more in number than control and PIH (No prenatal mortality) but this was not statistically significant. Chamberlain et al.(1970) showed a prenatal mortality rate of $3.37 \%$ in severe PIH and eclampsia. ${ }^{14}$ The effect of parity on PE has been well recognized. Zuspan FP et al. and Roberts JM et al. stated that PIH, PE and Eclampsia are considered to be a disease largely associated with first pregnancies. ${ }^{15,16}$

The prevailing hypothesis for the increased risk reported for nulliparous women is that after the first pregnancy, the maternal immune system would have 'recognized' the paternal antigens and developed a greater immune tolerance towards the same antigens in subsequent pregnancies. This implies that, in nulliparous women the impaired immunological tolerance experienced is largely as a result of their first exposure to the paternal antigens, which results in disordered placentation, a common feature of PE. ${ }^{17}$ This study did demonstrate and support the association.

This study showed the weight of a newborn baby is significantly low in PIH and PE. This is in concordance with the study conducted by Narasimha A et al.,Kartha S et al., Udainia A et al. ${ }^{1,2,18}$ Similar to our study, Majumdar S et al. ${ }^{19}$ also found that the MBW of new born babies were $2.8 \mathrm{Kg}$ in the control group and 2.04 $\mathrm{Kg}$ in the hypertensive group. Babies of mothers with poorly controlled PIH were mostly small for date.

Placenta weighs normally $450-500$ g. Fox H have shown that placenta tend to be smaller in $\mathrm{PE}$ than those in uncomplicated pregnancies. ${ }^{20}$ It is a well-established fact that blood flow to the placenta is reduced in PIH and this result in a small fetus with poor growth. Kambale $\mathrm{T}$ et $\mathrm{al}^{21}$ showed that the placentas were lighter in $\mathrm{PIH}$ and there was a reduction in weight with increasing grade of PIH. Narasimha Aet al. ${ }^{1}$ showed that the average weight of the normal placenta was $500 \mathrm{~g}$ and the weight was $<500 \mathrm{~g}$ in mild and severe cases of PE. The lowest recorded weight was $150 \mathrm{~g}$. Kartha $\mathrm{S}$ et al reported that the placental weight of normal pregnancy was $520 \mathrm{~g}$, and that of PIH were $375 \mathrm{~g}^{2}$ This was in concordance with the study conducted by Majumdar S et al. ${ }^{19}$ The same thing was noted by the study conducted in Massachussets dept of Pathology in $2008 .^{2}$

This study showed a mean placental weight of $\mathrm{PIH}$ and PE (450 g and $413.4 \mathrm{~g}$ respectively) significantly less than the normal pregnancy $(526 \mathrm{~g})$. This is in accordance to the studies performed by other authors as mentioned above. Contradictory findings of heavier placentas in cases of hypertensive pregnancies have been explained by different hypothesis. Wigglesworth (1962) has observed some degree of compensatory hypertrophy in the placental mass leading to increase in the placental weight. This may be a consequence of placental insufficiency, secondary to inadequate utero -placenta blood flow. ${ }^{22}$ Kartha $\mathrm{S}$ et al. also reported that the placental volume of the control group was $567.9 \mathrm{~cm}^{3}$ and for the hypertensive group were $397 \mathrm{cubic} \mathrm{cm}^{2}$ The mean placental volume in normal pregnancy, PIH and PE of the current study were $669.8 \mathrm{cc}, 352 \mathrm{cc}$ and $348.9 \mathrm{cc}$ respectively. These findings are similar to the study of Kartha $\mathrm{S}$ et al. and Udainia 
A et al. (2004). ${ }^{2,18}$ Fox H (1997) noted that in many hypertensive gestations there is decreased feto -placental weight ratio because of a compensatory hypertrophy of the placenta under the influence of unfavorable maternal environment. $^{23}$

The difference in the mean fetal birth weight observed by different researchers may be due to various factors such as socioeconomic status, races, and nutrition of mother. Fox reported hypertrophy of placental mass in response to chronic hypoxia in hypertensive cases.$^{23}$ This hypertrophy along with low birth weight of fetuses contributes to low fetoplacental weight ratio. In the study by KambaleT et al.,fetoplacental ratio was 5.38:1. ${ }^{21}$ Majumdar $\mathrm{S}$ et al. $^{19}$ observed reduced fetoplacental weight ratio with increasing degree of PIH. Majumdar S et al. stated that the gross anatomic features of placentas e.g infarcted areas, calcified areas and marginal insertion of the umbilical cord in the study groups show significant increase in value when compared to that of the control group. ${ }^{19}$ This is in concurrence with the findings of Udainia A et al. ${ }^{18}$ (2004) who had observed a similar increase in the incidence of placental infarction with severity of toxaemia.

This study showed $15 \%, 28.5 \%$ and $47.8 \%$ of placentas with marginal insertion of umbilical cord in control, PIH and PE cases, but not statistically significant. However marginal insertion of umbilical cord is significantly increased in PE than in the control $(p=0.02)$. Wide variations in the incidence of placental infarcts have been reported by Fox and Langley ${ }^{24}$ (1973), ranging from $34 \%$ in women with mild $\mathrm{PE}$ to $60 \%$ in women with the severe form of the disease. This study showed infarction in 5 cases (71.5\%) in $\mathrm{PIH}$ and 20 cases $(86.2 \%)$ in $\mathrm{PE}$ which is comparable with Narasimha A et al $(41 \%) .{ }^{1}$ The incidence of infarction is significantly greater than that of normal pregnancy. However this study includes cases with few scattered areas of necrosis $(<5 \%)$ which is normally present in placentas with normal pregnancy. This might be the reason for increased cases of infarction in this study. If we include moderate to severe infarction only the percentage will be $14.2 \%$ in $\mathrm{PIH}$ and $75.4 \%$ in $\mathrm{PE}$ which is similar to other studies. 1,2

Histological abnormalities such as the presence of villous hypermaturity, lymphohistiocyticvil- litis, avascular villi, perivillous fibrin deposits, hypovascular villi (Hyalinization), stromal fibrosis, calcification and vessel wall thickening were observed significantly more in the hypertensive placentas, which is in agreement with other studies of Krilessi V et al., Narasimha A et al., Majumdar S et al. and Akhlaq M et al. ${ }^{1,4,9,19}$ Similar to our study Majumdar S et al. and Narasimha A et al. found an increase in the number of syncytial knots. It is an indication of excessive aging due to either postmaturity or a disease state causing placental insufficiency. ${ }^{1,19}$

\section{CONCLUSION}

This study showed that the weight and volume of the placentas were found to be much lower in cases of PIH and PE than the control. Similarly, preterm, nulliparous deliveries, low mean birth weight of babies, lower feto-placental weight ratio and the gross abnormalities like incidence of ischemia, infarction/necrosis were significantly more in placentas of PIH and PE than in placentas of control. Histological abnormalities such as the presence of villous hypermaturity, lymphohistiocyticvillitis, Avascular villi, perivillous fibrin deposits, Hypovascular villi (Hyalinization), stromal fibrosis, Calcification and vessel wall thickening were observed significantly more often in the hypertensive placentas.

\section{CONFLICT OF INTEREST}

None declared

\section{REFERENCES}

1. Narasimha A, Vasudeva DS. Spectrum of changes in placenta in toxemia of pregnancy. Indian J Pathol Microbiol 2011;54:15-20.

2. Kartha S, Poothiode U, Jayalakshmy PS. Placental pathology in pregnancy induced hypertension. J Med Dent Sci 2014;3(35):9272-8.

3. Cunningham F, Leveno K, Bloom S, Hauth J, Gilstrap L, Wenstrom K. Williams Obstetrics. 22nd ed. New York: McGraw-Hill Professional; 2005.

4. Krielessi V, Papantoniou N, Papageorgiou L, Chatzipapas I, Manios E, Zakopoulos N, et al. Placental pathology and blood pressure's level in women with hypertensive disorders in pregnancy. Obstet GynecolInt 2012;684083. Available from: URL: doi:10.1155/2012/684083.

5. Backes CH, Markham, Moorehead KP, Cordero L, Nankervis CA, Giannone PJ. Maternal preeclampsia and neonatal outcomes. J Pregnancy 2011;13(2):1-7

6. Myatt L. Role of placenta in preeclampsia. Endocrine 2002;19(1):103-11. 
7. Misra DP, Salafia CM, Miller RK, Charles AK. Non -linear and gender-specific relationships among placental growth measures and the fetoplacental weight ratio. Placenta 2009;30(12):1052-7.

8. Soma H, Yoshida K, Mukaida T, Tabushi Y. Morphologic changes in the hypertensive placenta. Contrib Gynecol Obstet 1982;9:58-75.

9. Akhlaq M, Nagi AH, Yousuf AW. Placental morphology in pre-eclampsia and eclampsia and the likely role of NK cells. Indian J Pathol Microbiol 2012;55:17-21.

10. Obed SA, Patience A. Birth weight and ponderal index in pre-eclampsia: A comparative study. Ghana Med J 2006;40:8-13.

11. Hansen JP. Older maternal age and pregnancy outcome: a review of the literature. Obstet Gynecol Surv 1986;41:726-42.

12. Lydakis C, Beevers M, Beevers DG, Lip GY. The prevalence of pre-eclampsia and obstetric outcome in pregnancies of normotensive and hypertensive women attending a hospital specialist clinic. Int $\mathrm{J}$ ClinPract 2001;55:361-7

13. Noor S, Halimi M, Faiz NR, Gull F, Akbar N. Magnesium Sulphate in the prophylaxis and treatment of eclampsia. J Ayub Med CollAbottabad 2001;16:125.

14. Chamberlain G, Phillip E, Howlett B, Masters K. In: British births, 2nd ed. Obstetric care. London:William Heineman Medical Books. 1970. p. 84.

15. Roberts JM, Redman CW. Pre-eclampsia: more than pregnancy-induced hypertension. Lancet 1993;341 (8858):1447-51.

16. Zuspan FP. New concepts in the understanding of hypertensive diseases during pregnancy: an overview. Clin Perinatol 1991;18:653-9.

17. Robertson SA, Bromfield JJ, Tremellen KP. Seminal 'priming' for protection from pre-eclampsia-a unifying hypothesis. J Reprod Immunol 2003;59 (2):253-65.

18. Udainia A, Jain ML. Morphological Study of Placenta in pregnancy Induced Hypertension with its Clinical Relevance. J AnatSoc India 2001;50(1):247.

19. Majumdar S, Dasgupta $H$, Bhattacharya K, Bhattacharya A. A study of placenta in normal and hypertensive pregnancies. J AnatSoc India 2005;54 (2)1-9.

20. Fox H. White infarcts of the placenta. J Obstet Gynaecol Br Commonw 1963;70:980-91.

21. Kambale T, Iqbal B, Ramraje S, Swaimul K, Salve S. Placental morphology and fetal implications in pregnancies complicated by pregnancy-induced hypertension. Med J DY PatilUniv 2016;9:341-7.

22. Wigglesworth JS. The Langhans layer in late pregnancy - a histological study of normal and abnormal cases. J ObstetGynecol 1962;69:355.

23. Fox H. Pathology of the placenta. 2nd ed. London, W.B. Saunders; 1997.

24. Fox H, Langley F. The pathology of infarction in perinatal morbidity and mortality. Biologic aneonatorum 1973;11:87. 